\title{
KESIAPAN ORANG TUA DALAM PENGELOLAAN PENDIDIKAN ANAK USIA DINI
}

\author{
Jamilah \\ STKIP PGRI Sumenep \\ jamilah@stkippgrisumenep.ac.id
}

\begin{abstract}
Abstrak
Penelitian bertujuan untuk menganalisis kesiapan orang tua dalam penyelenggaraan program pendidikan anak usia dini Tarbiyatus Shibyan. Jenis penelitiannya menggunakan penelitian kualitatif dengan pendekatan studi kasus. Lokasi penelitian ini dilaksanakan di Pendidikan Anak Usia Dini Tarbiyatus Shibyan Jadung Dungkek Sumenep. Subjek penelitian adalah ornag tua yang menyekolahkan anaknya di pendidikan anak usia dini Tarbiyatus Shibyan. Pengumpulan datanya menggunakan wawancara, observasi, dokumentasi dan Focus Group Discussion. Analisis datanya terdiri dari pengumpulan data, penyajian data serta penarikan kesimpulan. Penelitian ini menghasilkan temuan bahwa kesiapan orang tua dalam penyelenggaraan pendididikan anak usia dini bersifat aktif.
\end{abstract}

Kata kunci: orang tua, kesiapan, PAUD, Tarbiyatus Shibyan

\begin{abstract}
The study aims to analyze the readiness of parents in the implementation of Tarbiyatus Shibyan's early childhood education program. This type of research uses qualitative research with a case study approach. The location of this study was carried out in Tarbiyatus Shibyan Jadung Dungkek Sumenep's Early Childhood Education. The subject of the study was an elderly person who sent his child to school in early childhood education Tarbiyatus Shibyan. The collection of data using interviews, observation, documentation and Focus Group Discussion. Data analysis consisted of data collection, data presentation and conclusion drawing. This research results in finding that the readiness of parents in organizing early childhood education is active.
\end{abstract}

Keywords: parents, readiness, early childhood, Tarbiyatus Shibyan

\section{Pendahuluan}

Tiap warga negara berhak untuk memperoleh pendidikan terutama dalam program pendidikan anak usia dini. Anak usia dini dalam kehidupannya berhak memperoleh perhatian dan perlakuan serius dari orang tua, lembaga pendidikan dan lingkungan sekitar.

Faktor penentu pendidikan yang berkualitas dan bermutu adalah perencanaan program yang matang salah satu perencaanaan program pendidikan anak usia dini dengan melibatkan orang tua dalam sebuah program.

Pembelajaran pendidikan anak usia dini yang ideal adalah program pendidikan anak usia dini mampu membuat perencanaan kegiatan belajar dalam proses pendidikan yang melibatkan anak- anak dan orang tua sehingga kegiatan pembelajaran tersebut lebih bermakna bagi kehidupan anak-anak di masa yang akan datang

Berdasarkan kenyataan di atas, mengisyaratkan bahwa perencanaan keterlibatan orang tua dalam proses pendidikan anak merupakan hal yang harus dilakukan pada setiap program pendidikan anak usia dini, sehingga program tersebut bisa mengoptimalkan pencapaian perkembangan, pertumbuhan serta tujuan program pendidikan anak secara maksimal.

Menurut Wortham ((2013, p. 47), kriteria pendidikan anak usia dini yang berkualitas salah satunya adalah memberikan pelayanan berdasarkan program yang berkualitas. Ciri-ciri pendidikan anak usia 
dini yang berkualitas yaitu: (a) Sesuai dengan prinsip kebutuhan perkembangan anak, (b) Mempunyai metode kurikulum yang selaras dengan kebutuhan. (c) menjalin hubungan komunikasi orang tua, guru dan anak. (d) Orang tua memberikan penilaian dan bertanggungjawab dalam mengevaluasi perkembangan anak (e) Adanya penghargaan dari orang tua terhadap pengetahuan anak-anaknya di rumah. (f) Memperhatikan karakter masingmasing anak dalam program pembelajaran dalam menjalin hubungan dengan guru.

Penyelenggaraan pendidikan ana usia dini mempunyai tujuan antara lain yaitu: (a) untuk mencetak anak Indonesia yang berkualitas, yaitu anak yang tumbuh dan berkembang sesuai dengan tingkat perkembangannya sehingga memiliki kesiapan yang optimal di dalam memasuki pendidikan dasar serta mengarungi kehidupan di masa dewasa. (b) untuk membantu menyiapkan anak mencapai proses kesiapan belajar (akademik) di sekolah secara optimal.

Anak usia dini merupakan pribadi yang akan menjalani suatu proses perkembangan pembelajaran secara terus menerus yang mendasar bagi kehidupan selanjutnya.

Usia 0-6 tahun merupakan rentang usia anak usia dini. Usia anak usia dini adalah usia pertumbuhan dan perkembangan anak dalam berbagai aspek sedang menjalani masa yang cepat dalam rentang perkembangan hidup manusia (Yuliani, 2009, p. 9).

Berdasarkan Fakta yang terjadi dapat diartikan bahwa kebanyakan orang tua yang rendah tingkat partisipasinya pada pendidikan anak usia dini, sehingga penyelenggaraannya belum terlaksana secara maksimal. Rendahnya tingkat partisipasi di sebabkan oleh faktor: (a) tingkat kesiapan perencanaan keterlibtan orang tua dalam memberikan dukungan dalam bentuk dana seperti kemauan orang tua menanggung biaya penyelenggaraan pendidikan anak usia dinibaik berupa uang maupan tenaga belum merata; (b) angagapan orang tua yang memiliki latar belakang pendidikan tinggi bahwa lembaga pendidikan anak usia dini merupakan awal dari jenjang pendidikan formal. Berbeda dengan orang tua yang tidak memiliki pendidikan tinggi menganggap bahwa belajar di program adalah pengalaman. Dimana orang tua yang menganggap pengalamannya hanya tamat SD akan beranggapan bahwa lembaga pendidikan anak usia dini tidak begitu penting; (c) Orang tua yang tidak memiliki pekerjaan (ibu rumah tangga) beranggapan bahwa dengan mengajarkan anak dirumah juga sudah cukup; (d) Bagi orang tua yang memiliki berpenghasilan rendah akan beranggapan bahwa pendidikan anak usia dini hanya akan membuang uang saja.

Dengan kata lain, rendahnya pengetahuan orang tua menjadai masalah pada program pendidikan anak usia dini. Banyak orang tua yang belum menyadari bahwa tanggung jawab terbesar dalam pendidikan anak ada pada orang tua, dan pendidik yang masih banyak yang belum kreatif, inovatif, dan menguasai tentang bagaimana pola pendidikan anak usia dini. Kesulitan cara dalam melibatkan orang tua menjadi makin bertambah terjadi pada keluarga dengan berpenghasilan rendah.

Dalam hal ini melibatkan perilaku orang tua dalam pendidikan anak-anaknya di keluarga dan sekolah dimaksudkan untuk mendorong kemajuan pendidikan anakanak mereka. Langkah-langkah dari partisipasi orang tua umumnya termasuk mutu dan hubungan komunikasi dengan para guru serta partisipasi dalam fungsi dan kegiatan mereka di sekolah.

Sesuai dengan Undang-Undang Nomor 20 Tahun 2003 tentang Sistem pendidikan Nasional (UU No. 20/2003 tentang Sisdiknas) Pasal 7, Ayat 1 yang menyatakan bahwa "orang tua berhak berperan serta dalam memilih satuan pendidikan dan memperoleh informasi tentang perkembangan anaknya".

Hal ini sesuai dengan pendapat Olsen dan Fuller (2004, p. 215) yaitu partisipasi orang tua dapat diartikan sebagai salah 
Jamilah

satu model perencanaan keterlibatan orang tua dalam rangka membenahi pendidikan pada program pendidikan anak usia dini untuk mengembangkan pembelajaran dan perkembangan anak dalam rangka meningkatkan proses dan hasil pendidikan di suatu program. Namun kesiapan orang tua dalam pendidikan anak usia dini masih dalam bentuk pasif misalnya orang tua sebagai penyedia layanan, sumber dan guru.

Beberapa hasil penelitian menyatakan bahwa partisipasi aktif orang tua dalam pendidikan telah dilakukan oleh banyak tokoh, diantaranya adalah Plowden yang memunculkan asumsi bahwa sekolah yang dapat mengkomunikasikan dengan baik kepada orang tua tentang kegiatan yang mereka lakukan di sekolah menghasilkan sikap yang baik dari orang tua (Powell, 2000,p.145). Keterlibatan aktif memberikan manfaat optimal bagi perkembangan anak, pendidik dan program pendidikan anak usia dini.

Jeynes (dalam Hornby, 2011, p. 1) menyatakan bahwa makna partisipasi orang tua adalah keterlibatan orang tua sebagai proses pembelajaran dan pengalaman pendidikan anak-anak mereka di program pendidikan anak usia dini

Pengertian ini menjelaskan bahwa partisipasi orang tua dalam pendidikan anak usia dini yang dimaksud oleh Jeynes (2007, p. 83) bahwa dengan hadirnya orang tua di program pendidikan anak usia dini termasuk dalam proses pembelajaran yang diikuti anak di kelas sehingga orang tua juga turut mengalami apa yang dialami oleh anak mereka dalam proses pendidikan yang diikutinya.

Oleh karena itu orang tua dan guru seharusnya berkolaborasi dalam memahami apa arti atau makna dari partisipasi orang tua dalam memberikan pendidikan yang utuh kepada anakanaknya, agar mereka dapat memutuskan bagaimana pendapat dan cara mereka dalam memberikan pendidikan anak mereka di program pendidikan anak usia dini.
Selanjutnya Morrison (1988, p. 322) mengatakan "Parent involvement is a process of helping parents use their abilities to benefit themselves, their children and the early childhood program" bahwa partisipasi atau keterlibatan orang tua adalah sebuah prosesdalam rangka membantu orang tua menggunakan segala kemampuan mereka untuk keuntungan mereka sendiri, anak-anak dan program anak usia dini.

Sesuai dengan pendapat Morrison di atas bahwa partisipasi orang tua dalam pendidikan anak dapat 'memberikan manfaat tidak hanya bagi orang tua, namun juga akan memberikan manfaat bagi anak maupun program pendidikan anak usia dini

Partispasi orang tua idealnya dimulai dari awal perencanaan program, pelaksanaan program, pengawasan serta evaluasi penyelenggaraan Pendidikan anak usia dini.

Terbukti dengan banyaknya orang tua belum dilibatkan secara langsung dalam penyelenggaraan program pendidikan anak usia dini. Hal ini disebabkan oleh berbagai faktor diantaranya kesibukan orang tua yang memliki berbagai kegiatan dan hal-hal lain yang terkait tentang pandangan orang tua mengenai pentingnya layanan pendidikan anak semenjak usia dini.

Partisipasi orang tua dapat meningkatkan kualitas program pendidiakn anak usia dini yang di dalamnya terdapat perencanaan program pendidikan anak usia dini dalam melibatkan orang tua sehingga dapat dirasakan manfaatnya bagi anak, orang tua dan program itu sendiri. Melalui berbagai usaha yang dilakukan pihak lembaga diharapkan masyarakat dan orang tua murid dapat terlibat secara aktif dan optimal dalam proses pendidikan di program pendidikan anak usia dini. Oleh karena itu perlu dikembangkan konsep kesiapan partisipasi orang tua dalam program pendidikan anak usia dini salah satunya yaitu perencanaan partisipasi.

Partisipasi orang tua pada penyelenggaraan pendidikan anak usia dini seharusnya terjadi Indonesia tak terkecuali 
di Kabupaten Sumenep. Pendidikan anak usia dini Tarbiyatus Shibyan merupakan lembaga pendidikan anak usia yang berada diwilayah pedesaan.

Realitas di lapangan menunjukkan bahwa kesiapan orang tua yang menyekolahkan anaknya pada pendidikan anak usia dini Tarbiyatus Shibyan masih rendah. Faktor lainnya adalah tingkat pendidikan orang tua. Dilihat dari pendidikan orang tua kebanyakan tamat SMP. Tingkat pengetahuan orang tua menjadi penentu keberhasilan anak di program anak usia dini.

Jadi menurut pandangan orang tua dengan menyekolahkan anaknya pada program pendidikan anak usia dini tersebut dapat meringankan bebannya pada saat orang tua bekerja si anak tidak bisa mengganggu aktivitasnya lagi karena sudah ada yang menjaganya di pendidikan anak usia dini tersebut.

Di sini orang tua hanya memberikan partisipasi dalam bentuk harta benda yaitu uang yang diberikan orang tua dalam memfasilitasi sarana prasarana yang ada di pendidikan anak usia dini tanpa mengetahui arti penting pendidikan anak usia dini bagi anaknya.

Penelitian ini bertujuan untuk menganalisis kesiapan orang tua dalam program pendidikan anak usia dini. Bentuk kesiapan partiipasi orang tua ada yang bersifat aktif dan bersifat pasif.

Kesiapan aktif artinya orang tua harus mendukung dan mengajak orang lain untuk meningkatkan pemahaman dalam mengembangkan serta meningkatkan hasil program pendidikan anak usia dini. Kesiapan pasif yaitu orang tua tidak menolak program pendidikan anak usia dini namun tidak mau terlibat secara langsung dalam penyelenggaraan program (Morrison 1988, p.324).

Karakteristik kesiapan program PAUD disajikan pada Tabel 1.

Tabel 1. Karakteristik Kesiapan Program PAUD

\begin{tabular}{|l|l|l|}
\hline No & \multicolumn{1}{|c|}{$\begin{array}{c}\text { Karakteristik kesiapan } \\
\text { Program PAUD bersifat } \\
\text { Aktif }\end{array}$} & \multicolumn{1}{c|}{$\begin{array}{c}\text { Karakteristik kesiapan Program } \\
\text { PAUD bersifat Pasif }\end{array}$} \\
\hline 1 & $\begin{array}{l}\text { Ada perencanaan program } \\
\text { partisipasi yang disusun bersama } \\
\text { dengan orang tua }\end{array}$ & $\begin{array}{l}\text { Ada perencanaan program partisipasi } \\
\text { tetapi orang tua tidak ikut menyusun } \\
\text { program. }\end{array}$ \\
\hline 2 & $\begin{array}{l}\text { Orang tua terlibat secara langsung } \\
\text { dengan memberikan saran kepada } \\
\text { program PAUD }\end{array}$ & $\begin{array}{l}\text { Orang tua terlibat secara langsung } \\
\text { tetapi tidak memberikan saran } \\
\text { kepada program PAUD, hanya diam } \\
\text { saja dan menerima hasil rapat. }\end{array}$ \\
\hline 3 & $\begin{array}{l}\text { Orang tua ikut serta dalam } \\
\text { program PAUD forum kelas dan } \\
\text { sekolah dan ikut terlibat dalam } \\
\text { penerimaan anak didik baru }\end{array}$ & $\begin{array}{l}\text { Orang tua tidak terlibat dalam } \\
\text { program PAUD }\end{array}$ \\
\hline 4 & $\begin{array}{l}\text { Orang tua menanyakan secara } \\
\text { langsung tentang perkembangan } \\
\text { anak di program PAUD }\end{array}$ & $\begin{array}{l}\text { Komunikasi orang tua melalui buku } \\
\text { penghubung untuk menanyakan } \\
\text { perkembanagn anaknya di program } \\
\text { PAUD }\end{array}$ \\
\hline
\end{tabular}

\section{Metode}

Penelitian ini merupakan penelitian kualitatif dengan menggunakan pendekatan studi kasus. Pelaksanaan penelitian berlangsung pada bulan Juli 2018 sampa dengan Desember 2018 di Pendidikan Anak Usia Dini Tarbiyatus Shibyan Dungkek Sumenep.

Subjek penelitian ini adalah orang tua yang anaknya sekolah pada program pendidikan anak usia dini Subjek penelitian ini menghasilkan informasi data yang ditarik dan dikembangkan secara purposive samping.

Pengumpulan datanya menggunakan observasi, wawancara, dan dokumentasi dan focus group discusssion. Analisis datanya menggunakan analisis kualitatif yang dikembangkan oleh Miles dan Huberman. 1994, p. 12) adalah 
Jamilah

penghimpunan data, reduksi, display, dan kesimpulan.

Data yang dikumpulkan dalam penelitian ini meliputi data tentang kesiapan orang tua dalamn pendidikan anak usia dini. Data tersebut berkenaan dengan arti penting partisipasi orang tua, bentuk, manfaat serta rekomendasi konsep partisipasi yang ada kaitannya dengan kondisi pendidikan anak usia dini Tarbiyatus Shibyan.

Hasil observasi diolah dengan menggunakan data deskriptif melalui wawancara, dokumentasi dan focus group discussion. Analisis dimulai dari data, yang dikumpulkan kemudian dilakukan reduksi data meliputi penyederhanaan data dengan memilih data yang dibutuhkan. Data hasil reduksi digolongkan sesuai dengan desain analisis yang telah dirancang yang kemudian di sajikan datanya. Setiap data reduksi yang telah digolongkan diverifikasi dengan berbagai kejadian di lapangan tentang kesiapan orang tua dalam perencanaan program pendidikan anak usia dini.

\section{Hasil dan Pembahasan}

Pelaksanaan Kesiapan Partisipasi Orang Tua di PAUD Tarbiyatus Shibyan

Keberhasilan dan kemajuan program pendidikan anak usia dini disebabkan oleh faktor kesiapan orang tua dalam penyelenggaranan program pendidikan anak usia dini. Faktor pendorong pertama dalam kesuksesan program pendidikan anak usia dini adalah dengan adanya dukungan dan keterlibatan orang tua dalam pendidikan anak usia dini.
Beaty (1984: 206) mengatakan dengan lingkungan dengan suasana baik dalam pembelajaran yang diberikan oleh pendidikan anak usia dini dapat menunjukkan jika program tersebut secara terbuka dapat membantu orang tua dalam menemukan cara yang tepat untuk terlibat dalam program pembelajaran anak mereka.

Keikutsertaan mereka ditunjukan dalam rapat, mengemukakan pendapat ketika rapat, seta terlibat dalam monitoring dan evaluasi kegiatan yang dilaksanakan pada program pendidikan anak usia dini.

Berdasarkan hasil focus group discussion melibatan orang tua pada program pendidikan anak usia dini antara lain: a) pertemuan antara orang tua dengan pengelola program pendidikan anak usia dini sebanyak tiga kali dalam satu semester, b) melaksanakan kelas orang tua pada program pendidikan anak usia dini minimal dua kali dalam setahun, c) orang tua hadir sebagai narasumber dalam kelas inspirasi yang diselenggarakan oleh pengelola program dan d) menyelenggarakan pentas seni pada akhir pembelajaran pendidikan anak usia dini..

Pada Program pendidikan anak usia dini Tarbiyatus Shibyan sudah ada perencanaan keterlibatan orang tua pada program pendidikan anak usia dini sehingga tingkat kesiapan partisipasi masih pada kesiapan aktif. Tingkatan partisipasi orang tua pada program PAUD adalah adanya perencanaan partisipasi orang tua bukan pada perencanaan program. Partisiapsi orang tua pada program pendidikan anak usia dini dilihat pada Tabel 2.

Tabel 2. Partisipasi Orang tua dalam Penyelenggaraan PAUD Tarbiyatus Shibyan

\begin{tabular}{|c|l|}
\hline No & \multicolumn{1}{|c|}{$\begin{array}{c}\text { Partisipasi Orang Tua dalam Peyelenggaraan } \\
\text { PAUD di PAUD Tarbiyatus Shibyan }\end{array}$} \\
\hline 1 & $\begin{array}{l}\text { Orang tua terlibat dalam perencanaan program PAUD meskipun } \\
\text { belum dilakukan secara maksimal }\end{array}$ \\
\hline 2 & $\begin{array}{l}\text { Orang tua membantu program perencanaan program belajar di } \\
\text { ruang kelas atau di aktivitas di luar }\end{array}$ \\
\hline 3 & $\begin{array}{l}\text { Orang tua terlibat aktif dalam event-event di PAUD seperti } \\
\text { Perayaan hari besar, lomba-lomba dan lain sebagainya }\end{array}$ \\
\hline 4 & $\begin{array}{l}\text { Orang tua terkadang ikut mengevaluasi proses pembelajaran } \\
\text { yang ada di PAUD sebingga kesadaran diri dari orang tua mulai } \\
\text { terlibat. }\end{array}$ \\
\hline
\end{tabular}


Bentuk Kesiapan Partisipasi Orang Tua Orang Tua sebagai Pelayan

Kesiapan aktif orang tua dalam acara acara yang diselenggarakan oleh PAUD, misalnya kegiatan perlombaan, kegiatan rutin dalam proses pembelajaran dan aktivitas lain yang ada di PAUD. Bentuk partisipasi pada kegiatan ini orang tua menyiapkan segala sesuatu yang berhubungan dengan workshop misalnya menyiapkan administrasi, membantu meyiapkan sarana dan prasana dan lain sebagainya.

\section{Orang Tua Sebagai Sumber}

Bentuk kesiapan partisipasi orang tua ini diwujudkan berupa sebagai sumber dana untuk membantu aktivitas di pogram PAUD. Sumbangan dana ini berasal dari orang tua yang mempunyai penghasilan yang tinggi yang peduli terhadap pendidikan anaknya. Wujud dukungan orang tua dengan pengelola program pada pendidikan anak usia dini di Tarbiyatus Shibyan ini masih terbatas dalam bentuk dana pemberian infaq dari orang tua untuk kebutuhan program pembelajaran di pendidikan anak usia dini Tarbiyatus Shibyan.

Menurut Uswatun Hasanah apabila mempunyai kelebihan dana untuk pembiayaan operasional lembaga serta dipergunakan untuk memenuhi kebutuhan pembelajaran anak dengan melengkapi alat permainan edukatif.

Orang tua ikut bertanggungjawab terhadap keamanan sekolah, partisipasi masyarakat juga dapat dilihat dalam memeperingati kegiatan hari besar nasional dan peringatan hari besar agama. misalnya wali murid menjadi penceramah dalam mengisi siraman rohani dan penyampaian pesan moral terhadap anak di program pendidikan anak usia dini.

\section{Orang Tua Sebagai Pendidik}

Bentuk kesiapan partisipasi orang tua bisa dilakukan dalam pembelajaran di kelas ketika guru pada hari tersebut berhalangan hadir. Hal ini disesuaikan dengan profesi masing masing orang tua, sedangkan cara atau metode yang diajarkan kepada anak usia dini disesuaikan dengan motto pembelajaran pendidikan anak usia dini yaitu dengan cara bermain sambil belajar, sehingga anak dapat mengembangkan potensi yang ada pada dirinya masingmasing.

Kegiatan yang bisa memberikan informasi tersebut bisa dilakukan dengan cara membacakan buku-buku cerita, bermain peran, melihat video pembelajran anak sehingga perkembangan pengetahuan dalam memperoleh pendidikan mulai tumbuh secara optimal.

\section{Faktor Kesiapan Orang Tua dalam Program PAUD}

Penelitian ini menunjukkan bahwa faktorfaktor kesiapan orang tua dalam penyelenggaraan pendidikan anak usia dini antara lain: (1)Tingkat Pendidikan (orang tua) dapat memberikan semangat belajar anak dan mendukung belajar anak di rumah sesuai dengan perkembangan anak. Kesiapan orang tua dalam kesiapan berpartisipasi pada program pendidikan anak usia dini paling banyak memeliki pendidikan yang lebih tinggi dibandingkan dengan orang tua yang tidak ikut serta berpartisipasi dalam program pendidikan anak usia dini.

Dari segi pendidikan orang tua yang paling rendah adalah mempunyai ijazah Sekolah Dasar dan tertinggi adalah Sarjana, tetapi kebanyakan mereka berpendidikan SMA. Sementara orang tua yang tidak terlibat pada program pendidikan anak usia dini tertinggi adalah berpendidikan SMA dan lainnya berpendidikan SMP dan SD. Sehingga pandangan mereka pada program pendidikan anak usia dini berbeda.

(2) Faktor ekonomi secara tidak langsung akan mempengaruhi kesiapan orang tua dalam program pendidikan anak usia dini. Orang tua dengan berpenghasilan tinggi sering terlibat katif karena mereka tidak memikirkan ekonomi keluarga. Hal ini berbeda dengan orang tua yang perpenghasilan rendah, karena mereka 
Jamilah

turut membantu suaminya bekerja untuk memenuhi kebutuhan keluarga mereka

Berdasarkan hasil focus group discussion antara pengelola pendidikan anak usia dini Tarbiyatus Shibyan dan orang tua yang menyekolahkan anaknya mengatakan fakto faktor waktu merupakan kendala orang tua dalam kesiapannya perpastispasi dalam program pendididkan anak usia dini. Selain itu adalah faktor materi, uang serta faktor pendidikan.

(3) Kesibukan orang tua menjadi faktor penghambat terlibatnya kesiapan orang tua dalam program pendidikan anak usia dini. Baik program pendidikan anak usia dini maupun orang tua mengaku kesulitan untuk mencari waktu yang tepat agar orang tua dapat hadir dalam program pendidikan .

Tetapi ada juga orang tua yang memiliki kesibukan di rumah tetapi orang tua masih memiliki tanggungjawab lain yang jika tugas dari suatu peran yang belum terselesaikan sehingga orang tua tidak dapat ikut serta pada program pendidikan anak usia dini.

\section{Manfaat Kesiapan dalam Program PAUD \\ Manfaat Terhadap Kualitas Program PAUD}

Peningkatan kualitas pendidikan dengan melibatkan orang tua dalam proses penyelenggaraan pendidikan anak usia dini, perlu dibentuk wadah komite sekolah yang dilibatkan secara langsung orang tua murid. Tujuan pembentukan komite untuk lebih meningkatkan tanggung jawab dan peran serta orang tua dalam penyelenggaraan program pendidikan anak usia dini, sehingga orang tua merasa ikut dilibatkan dan dapat berpartisipasi melalui organisasi yang mereka sudah kenal.

Keberadaan pendidikan anak usia dini telah memberikan dampak positif, sehingga masyarakat tergerak untuk berpartisipasi karena kegiatan tersebut dinilai memberikan manfaat dalam kehidupan dan mecerdaskan anak bangsa
Manfaat Terhadap Anak.

Manfaat kesiapan orang tua dalam pendidikan bagi anak yaitu: (1) Anak menjadi bangga ketika belajar pada program pendidikan anak usia dini tanpa adanya perbedaan suku dan latar belakang status ekonomi, atau tingkat pendidikan orang tua, (2) anak merasa tenang dengana danya keberadaan orang tua srhingga dapat mencapai peringkat, nilai, dan kehadiran yang lebih baik, (3) anak-anak menjadi lebih disiplin sehingga anak anak mempunyai keinginan yang lebih tinggi untuk belajar di pendidikan anak usia dini, (5) Anak-anak memiliki sikap positif terhadap pendidikan anak usia dini sering memberikan hasil berupa peningkatan sikap yang membaik di program pendidikan anak usia dini dan jarang melanggar peraturan yang berlaku, (6) peserta didik yang berasal dari kebudayaan yang berbeda cenderung melakukan hal yang lebih baik jika pihak orang tua dan tenaga pendidik bekerja sama untuk menjembatani perbedaan budaya yang ada di lingkungan keluarga dan program pendidikan anak usia dini. Pada masa tumbuh kembang anak usia dini adalah masa emas yang tidak boleh dilewatkan para orang tua.

Selayaknya orang tua memahami, mendampingi dan menstimulasi setiap aspek perkembangan anak sesuai dengan tahap pencapaian perkembangannya, salah satu moment yang tidak boleh dilalaikan orang tua yaitu perilaku moral anak. Perilaku moral layaknya menjadi sorotan utama bagi orang tua dalam masa emas anak (golden age).

\section{Manfaat Terhadap Orang Tua}

Kesiapan aktif orang tua mengungkapakan sejauh mana orang tua hadir dan terlibat secara langsung dalam kehidupan anak mereka dan dapat meningkatkan kepuasan dan minat dalam memberikan pendidikan anak mereka. Manfaat lain yang kesiapan orang tua dalam pendidikan di sekolah juga diyakini 
memiliki hubungan tren positif terhadap kemitraan antara sekolah dengan orang tua serta bentuk konstruksi peran aktif kesiapan orang tua dalam pendidikan anak-anak di sekolah.

Selain kesadaran kesiapan orang tua, keberhasilan program pendidikan anak usia dini dapat menciptakan suasana belajar yangnyaman bagi orang tua dalam program pendidikan anak usia dini. Kesadaran kesiapan orang tua juga menjadi faktor pendukung orang tua di program pendidikan anak usia dini. Suasana yang tenang dan tentram dalam program pendidikan anak usai dini membuat orang tua bisa menerima dengan baik program pembelajaran pada program pendidikan anak usia dini serta orang tua dengan senang hati bersedia terlibat secara aktif pada program pendidikan anak mereka.

\section{Konsep Yang Dihasilkan}

Hubungan yang kuat antara program anak usia dini dan keluarga terutama orang tua merupakan komponen penting yang sesuai dengan tahapan perkembangan anak mereka.

Keterlibtan orang tua pada program pendidiakn anak usia dini ini berlangsung dalam program pendidikan anak usai dini dan di luar program pendidikan anak usia dini, termasuk komunikasi yang melibatkan proses belajar anak.

Hasil focus group discussion menyatakan bahwa antara pendidikan anak usai dini Tarbiyatus Shibyan dengan para pemerhati pendidikan anak usia dini menghasilkan rekomendasi konsep kesiapan perencanaan keterlibtan orang tua pada pendidikan anak usia dini dengan beberapa indikator kesiapan keterlibatan orang tua yang berasal dari tingkatan partisipasi orang tua pada program pendidikan anak usia dini tersaji dalam tabel 3

Tabel 3. Bentuk Partisipasi Orang tua Menurut Morrison

\begin{tabular}{|c|c|c|}
\hline No & Aspek & Aspek Pengembangan \\
\hline \multirow[t]{5}{*}{1} & \multirow[t]{5}{*}{$\begin{array}{l}\text { Orang Tua sebagai } \\
\text { pelayan }\end{array}$} & $\begin{array}{l}\text { Ketrampilan pengasuhan dan membesarkan } \\
\text { anak }\end{array}$ \\
\hline & & Mengatur kondisi rumah \\
\hline & & Memenuhi kelengkapan belajar anak \\
\hline & & Menyediakan meja dan kursi belajar \\
\hline & & Membuat perpustakaan keluarga \\
\hline \multirow[t]{4}{*}{2} & \multirow{4}{*}{$\begin{array}{l}\text { Orang Tua sebagai } \\
\text { Sumber }\end{array}$} & Meningkatkan komunikasi antar masyarakat \\
\hline & & Menjalin kerjasama dengan masyarakat \\
\hline & & Komunikasi yang lancar dengan anak \\
\hline & & $\begin{array}{l}\text { Komunikasi secara langsung antara guru dan } \\
\text { orang tua }\end{array}$ \\
\hline \multirow[t]{3}{*}{3} & \multirow{3}{*}{$\begin{array}{l}\text { Menjadi PendidikAtau } \\
\text { Guru }\end{array}$} & Menjadi guru di kelas \\
\hline & & $\begin{array}{l}\text { Pemberian tugas dan mengatur jadwal anak di } \\
\text { rumah dan sekolah }\end{array}$ \\
\hline & & $\begin{array}{l}\text { Menyumbangkan tenaga dan dana bagi } \\
\text { sekolah }\end{array}$ \\
\hline
\end{tabular}

Dari hasil wawancara, Focus Group Discussion orang tua belum dilibatkan dalam pengambilan keputusan terkait kegiatan pembelajaran yang di dalam kelas. Hasil FGD ini mengindikasikan bahwa tingkat kesaiapan partisipasi orang tua masih pasif dan rendah di mana partisipasi orang tua cenderung dalam bentuk bantuan layanan, bantuan dana program pendidikan anak usia dini, bahkan belum pada tingkat 
Jamilah

tinggi yaitu pengambilan keputusan tentang program pendidikan anak usia dini. Hasil dari FGD menghendaki adanya perencanaan partisipasi pada level tinggi yaitu pada level pengambilan keputusan. Berbeda halnya dengan keterlibatan orang tua dalam administrasi, seluruh sekolah dalam subyek penelitian ini menentukan administrasi.

Selain itu konsep yang dihasilkan merupakan jawaban dari masalah-masalah yang dihadapi oleh program pendidikan anak usia dini dan dikeluhkan oleh para orang tua (keluarga), terutama terkait dengan masalah perilaku anak dan akademik sehingga perencanaan pengelolaan program itu bisa dilaksanakan dengan baik.

Model yang sesuai dengan kesiapan partisipasi orang tua dalam program pendidikan anak usia dini adalah model kemitraan (Patnership model). Model ini diperlukan oleh program pendidikan anak usia dini untuk meningkatkan kesiapan orang tua dalam program pendidikan anak usia dini.

Oleh kerena itu orang tua terlibat aktif secara langsung pada pendidikan anak usia dini baik di rumah maupun program pendidikan anak usia dini merupakan hubungan yang positif terhadap proses pembelajaran dan prestasi belajar anak di pendidikan anak usia dini, maka dapat dijelaskan bahwa orang tua yang tidak terlibat dalam program pendidikan anak usia dini akan mengalami berbagai kendala dalam proses dan prestasi belajar anak.

Meningkatkan kualitas program pembelajaran pada anak usia dini melalui keterlibatan orang tua dapat digunakan berbagai cara dalam meningkatkan kualitas pembelajaran di program pendidikan anak usia dini. Program partisipasi orang tua perlu dipahami bahwa pengelola program, pendidik dan orang tua sebelum mereka merancang program pembelajaran, seharusnya mereka memiliki kesiapan yang sama dalam peningkatan program.

Dengan memiliki kesiapan yang sama antara orang tua dengan pengelola program dalam program pembelajaran yang dirancang sesuai dengan kebutuhan pertumbuhan dan perkembangan anak. Meskipun orang tua sangat senang dalam setiap program dan sekolah mengupayakan berbagai cara, pada kenyataannya tidak semuanya berjalan lancar dikarenakan beberapa faktor penghambat yang terjadi di lapangan.

Berbagai upaya telah dilakukan program pendidikan anak usai dini untuk melibatkan orang tua melalui komunikasi proaktif, mencarikan waktu yang tepat dalam kesiapan orang tua terlibta secara langsung pada program pendidikan anak usia dini sehingga bisa menciptakan lingkungan yang ramah. Komunikasi yang terjalin secara kontinyu yakni berupa buku penghubung.

Kepasifan orang tua dalam partisipasi program pendidikan anak disebabkan tingkat kesiapan orang tua masih pada level satu dan tingkat kesiapan pendidik di level 2 dengan kesiapan pasif.

Peningkatan mutu program pembelajaran anak usia dini bisa melalui kesiapan keterlibtan orang tua dapat digunakan sebagai salah satu cara dalam meningkatkan kualitas pembelajaran pada program pendidikan anak usia dini.

Kesiapan partisipasi orang tua perlu dipahami oleh pendidik dan orang tua sebelum mereka merancang program pembelajaran, sehingga mereka memiliki kesiapan perencanaan penyelenggaraan yang sama. Dengan kesiapan perencanaan aktif dari orang tua, pendidik dan lembaga tersebut disesuiakan dengan kebutuhan pertumbuhan dan perkembangan anak sehingga mereka menjadi anak yang berkualitas dalam mencapai pendidikannya.

\section{Kesimpulan}

Simpulan penelitian ini adalah bahwa pelaksananaan kesiapan partisiapsi orang tua di program pendidikan anak usia dini Tarbiyatus Shibyan dalam kesiapan aktif. Bentuk partisipasi orang tua dalam penyelenggaraan pendidikan anak usia dini 
Tarbiyatus Shibyan masih berbentuk sebagai penyedia layanan, sumber serta sebagai pendidik, sehingga belum menjangkau pada peningkatan kualitas program pendidikan anak usia dini. Faktor yang mempengaruhi kesiapan partisipasi orang tua adalah faktor latar belakang orang tua yaitu faktor pendidikan, penghasilan dan sosial budaya serta faktor pendidik yang ada dalam program pendidiakn anak usai dini. Manfaat partisipasi orangtua bisa dirasakan oleh anak, orang tua dan pengelola program.

Kesiapan orang tua terlibat dalam penyelenggaraan pendidikan anak usi dini harus pada tingkatan level yang tinggi, hubungan silaturahmi dan kerjasama antara lembaga pendidikan anak usia dini
Tarbiyatus Shibyan tercapai secara maksimal sehingga dapat meningkatkan kesiapan peran orang tua dalam program pendidikan anak usia dini. Sebagai tindak lanjut penelitian diharapkan perlu adanya penelitian tindak lanjut terutama dalam pendekatan kuantitatif yang dapat menyajikan data dan hipotesa serta mengembangkan konsep kesiapan orang tua dalam program pendidikan anak usia dini selanjutnya.

\section{DAFTAR PUSTKA}

Beaty, J. J. (1984). Skills for Preschool Teachers. Columbus: Charles E. Merrill Publishing Company.

Dwiningrum, Siti Irene A. (2011). Desentralisasi dan partisipasi masyarakat dalam pendidikan: suatu kajian teoretis dan empirik, Yogyakarta: Pustaka Pelajar.

Hornby, G. (2011). Parental involvement in childhood education: Building effective schoolfamily partnership. New York: Springer Sciencet Business Media.

Hornby, G. dan Rayleen, L. (2011). Barriers to parental involvment in education: an explanatory model. College of education - Univercity of Canterbury, New Zeland.

Jeynes, W.H. (2007). The relation between parental involvement and urban secondary school student academic achievement: A meta-analysis. Urban Education, 42(1), 82-110.

Milles, M.B. \& Huberman, A.M. (1994). Qualitative data analysis. Beverly Hills: Sage Publication.

Morrison, G. S. (1988). Education and development of infant, toddlers, and preschoolers. London: Scott Foresman and company

Morrison, G. S (1988). Early childhood education today. Columbus: Merill Publishing company.

Sujiono, Y.N. (2011) Konsep dasar pendidikan anak usia dini, Jakarta: PT Indeks. 
Jamilah

Olsen, G. \& Fuller, M. L. (2003). Home-school relations: working successfully with parent and families. (2nd ed). Boston: Allyn and Bacon.

Powell, D.R. (2000). Relation between families and early childhood programs. $\mathrm{Http}: / /$ Ecap.crc.illionis.edu/pubs/ connecting/powell.pdf 141-154

Undang-Undang Nomor 20 Tahun 2003 Tentang Sistem Pendidikan Nasional 